\title{
PENINGKATAN KEMAMPUAN ANAK USIA DINI MENGENAL LAMBANG BILANGAN MELALUI MEDIA PLAYDOUGH
}

\author{
Sumardi $^{1}$, Taopik Rahman ${ }^{2}$, Iis Syifa Gustini ${ }^{3}$ \\ ${ }^{1}$ Program Studi PGPAUD Universitas Pendidikan Indonesia Kampus Tasikmalaya \\ ${ }^{2}$ Program Studi PGPAUD Universitas Pendidikan Indonesia Kampus Tasikmalaya \\ ${ }^{3}$ Program Studi PGPAUD Universitas Pendidikan Indonesia Kampus Tasikmalaya \\ Email : opik@upi.edu
}

(Received: September 2017; Accepted: Oktober 2017; Published: Desember 2017)

\begin{abstract}
This research aimed to improve the ability to recognize the symbol of number with playdough in Group A TK WijayaKusumah / Kartika XIX-26 Tawang District Tasikmalaya.This research was a classroom action research using Kemmis and Taggart model which was implemented in 3 cycles. The subjects of this study were 12 children of group A. Data collection techniques in this study were observation and documentation. Data analysis technique used was descriptive qualitative.The results showed that there was an increase in the ability to recognize the symbols of number through playdough media in the children of group A TK WijayaKusumah / Kartika XIX-26 Tawang Tasikmalaya. This was indicated by the increase of observation result of cycle I, cycle II, and cycle III. Prior to the implementation of the act, the child's ability to recognize the number symbol on the criteria developed very well is 3 children or with an average percentage of $27.8 \%$. In the implementation of cycle I, the ability of children to recognize the symbol of numbers on the criteria developed very well increased to 4 children or with average percentage of $30.6 \%$. In the implementation of cycle II, the ability of children to recognize the symbol of numbers on the criteria developed very well increased to 8 children or with an average percentage of 63.9\%. In the implementation of cycle III, the ability of children to recognize the number symbol on the criteria developed very well increased significantly to 10 children or with an average percentage of $86.1 \%$.
\end{abstract}

Keywords: the ability of children to recognize the symbol of numbers, playdough media, early childhood.

\begin{abstract}
ABSTRAK
Penilitian ini bertujuan untuk meningkatkan kemampuan mengenal lambang bilangan melalui media playdough pada anak kelompok A TK Wijaya Kusumah / Kartika XIX-26 Kecamatan Tawang Kota Tasikmalaya.Penelitian ini merupakan penelitian tindakan kelas menggunakan model Kemmis dan Taggart yang dilaksanakan dalam 3 siklus. Subjek penelitian ini adalah anak kelompok A yang berjumlah 12 anak. Teknik pengumpulan data dalam penelitian ini yaitu observasi dan dokumentasi. Teknik analisis data menggunakan deskriptif kualitatif. Hasil penelitian menunjukkan adanya peningkatan kemampuan mengenal lambang bilangan melalui media playdough pada anak kelompok A TK Wijaya Kusumah / Kartika XIX-26 Kecamatan Tawang Kota Tasikmalaya. Hal ini ditunjukkan dengan adanya peningkatan hasil observasi siklus I, siklus II, dan siklus III. Sebelum dilaksanakan tindakan kemampuan anakmengenal lambing bilangan pada kriteria berkembang sangat baik rata-rata sebanyak 3 anak atau dengan rata-rata presentase $27,8 \%$. Pada pelaksanaan siklus I, kemampuan anak mengenal lambing bilangan pada kriteria berkembang sangat baik meningkat menjadi 4 anakataudengan rata-rata presentase 30,6\%. Pada pelaksanaansiklus II, kemampuan anak mengenal lambing bilangan pada kriteria berkembang sangat baik meningkat menjadi 8 anak atau dengan rata-rata presentase 63,9\%. Pada pelaksanaan siklus III kemampuan anak mengenal lambing bilangan pada kriteria berkembang sangat baik meningkat signifikan menjadi 10 anak atau dengan rata-rata presentase $86,1 \%$.
\end{abstract}

Kata kunci: kemampuan anak mengenal lambang bilangan, media playdough, anak usia dini. 


\section{PENDAHULUAN}

Pendidikan anak usia dini ditujukan kepada anak usia 0 sampai 6 tahun. Pendidikan anak usia dini bertujuan untuk menstimulus pertumbuhan dan perkembangan anak usia dini agar lebih optimal dan kesiapan terhadap jenjang pendidikan selanjutnya.Anak usia dini berada pada masa keemasan (golden age) karena pada masa ini anak mengalami pertumbuhan dan perkembangan yang sangat pesat. Masa keemasan ini terjadi sekali sepanjang rentang kehidupan manusia. Pada masa ini anak mudah menyerap dan menerima informasi dari lingkungan sekitarnya. Masa ini merupakan masa yang tepat untuk meletakkan dasardasar pengembangan berbagai aspek perkembangan sebagai bekal untuk kehidupannya kelak. Dalam Permendikbud No. 146 tahun 2014 tentang kurikulum 2013 PAUD menyebutkan bahwa aspek perkembangan pembelajaran anak usia dini meliputi nilai agama dan moral, fisik motorik, kognitif, bahasa, sosio-emosional, dan seni.

Salah satu aspek perkembangan yang harus dikembangkan dalam pembelajaran anak usia dini adalah aspek kognitif.Dalam Permendikbud No. 137 Tahun 2014 tentang Standar Nasional PAUD menyebutkan bahwa aspek kognitif meliputi:

Belajar dan pemecahan masalah, mencakup kemampuan memecahkan masalah sederhana dalam kehidupan sehari-hari dengan cara fleksibel dan diterima sosial serta menerapkan pengetahuan atau pengalaman dalam konteks yang baru;

Berfikir logis, mencakup berbagai perbedaan, klasifikasi, pola berinisiatif, berencana, dan mengenal sebab-akibat;

Berpikir simbolik, mencakup kemampuan mengenal, menyebutkan, dan menggunakan konsep bilangan, mengenal huruf, serta mampu merepresentasikan berbagai benda dan imajinasinya dalam bentuk gambar.

Dalam Permendikbud No.137 tahun 2014 tentang STPPA (Standar Tingkat Pencapaian Perkembangan Anak) disebutkan bahwa indikator yang harus dicapai untuk anak usia 4-5 tahun yaitu membilang banyak benda 1-10, mengenal konsep bilangan, dan mengenal lambang bilangan.

Pengenalan lambang bilangan sangat penting bagi anak usia dini. Banyak hal disekitar anak yang berhubungan dengan lambang bilangan. Lambang bilangan merupakan aspek dasar dalam matematika. Wortham (2006, hlm. 233) mengatakan bahwa "Mathematics experiences prepared for preschool children should take into account the child cognitive limitations and present a minimum of perceptual difficulties". Pengalaman matematika harus disesuaikan dengan perkembangan kognitif anak agar meminimalkan kesulitan persepsi. Mengenalkan lambang bilangan untuk anak usia dini harus disesuaikan dengan perkembangan kognitif anak. Dengan mengenal lambang bilangan akan memudahkan anak dalam menyampaikan dan menafsirkan berbagai informasi. Pada awalnya anak mampu menyebutkan bilangan tanpa mengetahui makna bilangan tersebut. Sejalan dengan perkembangan dan pengalaman yang diperoleh anak akan mampu mengenal lambang bilangan.

Para pendidik seringkali mengenalkan lambang bilangan kepada anak hanya dengan menuliskan lambang bilangan dipapan tulis atau memberikan lembar kerja kepada anak kemudian anak diberi tugas untuk mengisi lembar kerja yang sudah disediakan sehingga anak mudah bosan dan pembelajaran kurang menantang bagi anak. Upaya pendidikan yang diberikan pendidik hendaknya dilakukan dengan kegiatan yang menyenangkan yang menggunakan strategi, 
metode, materi/bahan media yang menarik dan mudah dipahami peserta didik (Ramaini, t.t., hlm 2). Guru sebaiknya menggunakan media yang menarik dalam pembelajaran mengenal lambang bilangan agar menarik perhatian anak, memfasilitasi keaktifan dan kreativitas anak. Cara pemberian stimulasi anak usia dini dengan memberikan atau menciptakan kegiatan yang mencakup berbagai aspek perkembangan anak dengan menyediakan berbagai fasilitas dan media yang dibutuhkan oleh anak usia dini sesuai dengan kebutuhannya (Yunikowati, 2014, hlm.2). Melalui media pembelajaran akan meningkatkan motivasi belajar anak sehingga anak antusias dalam pembelajaran.

Berdasarkan observasi di kelompok A TK Wijaya Kusumah / Kartika XIX-26 menunjukkan bahwa kemampuan anak mengenal lambang bilangan belum optimal. Hal ini ditandai dengan ada anak yang belum mampu menunjuk lambang bilangan, meniru lambang bilangan, menguhubungkan lambang bilangan dengan jumlah benda.

Berdasarkan observasi awal diketahui bahwa penyebab kemampuan anak mengenal lambang bilangan belum optimal adalah pembelajaran yang lebih menekankan pada pemberian tugas, guru lebih banyak menjelaskan secara lisan. Selain itu minimnya penggunaan media pembelajaran, guru lebih sering menggunakan LKA biasa dan buku tulis sebagai sarana pembelajaran sehingga pembelajaran kurang menantang bagi anak.

Salah satu upaya untuk meningkatkan kemampuan anak mengenal lambang bilangan di TK Wijaya Kusumah / Kartika XIX-26 yaitu melalui penggunaan media playdough. Playdough merupakan adonan yang mudah dibentuk sesuai dengan imajinasi anak.Melalui media playdough akan memberikan pengalaman langsung kepada anak untuk mengenal lambang bilangan. Bruner (dalam Sriningsih, 2009, hlm.29) mengatakan bahwa dalam kegiatan pembelajaran anak sebaiknya diberikan kesempatan untuk memanipulasi bendabenda atau alat peraga, sehingga anak dapat melihat langsung bagaimana keteraturan serta pola-pola yang terdapat pada benda yang sedang diperhatikannya. Ardyatmika, A., Parmiti, D. \& Ujianti, P. (2016, hlm. 2) mengatakan bahwa "kegiatan yang menggunakan media playdough tidak membuat anak menjadi malas, karena anak akan terus menerus menggunakan daya imajinasinya untuk membuat bentuk-bentuk baru dan unik" Melalui media playdough anak terlibat secara aktif dalam kegiatan pembelajaran sehingga membantu anak menyerap informasi secara optimal mengenai lambang bilangan. Nurjatmika (2012, hlm. 99) mengatakan bahwa “...dengan bermain playdough anak-anak tak hanya memperoleh kesenangan, tapi juga pendidikan yang bermanfaat bagi mereka di masa depan". Penggunaan media playdough sangat menyenangkan bagi anak sehingga anak antusias dalam pembelajaran mengenal lambang bilangan.

Berdasarkan pertimbangan dan alasan diatas, maka diwujudkan dalam suatu tindakan penelitian kelas yang berjudul "Peningkatan Kemampuan Anak Usia Dini Mengenal Lambang Bilangan melalui Media Playdough" pada anak kelompok A TK Wijaya Kusumah / Kartika XIX-26 Kecamatan Tawang Kota Tasikmalaya.

\section{TINJAUAN PUSTAKA}

\section{Pengertian Anak Usia Dini}

Anak usia dini merupakan anak yang berada pada rentang usia $0-6$ tahun. Sujiono (2012, hlm. 6) menyebutkan bahwa anak usia dini adalah sosok individu yang sedang menjalani suatu proses perkembangan dengan pesat dan fundamental bagi kehidupan selanjutnya. 
Anak usia dini memiliki karakter yang khas dan variatif. Kekhasan tersebut akan tampak pada usia 0 sampai 6 tahun. Pada masa ini sangat menentukan pembentukan kepribadian anak dan perkembangan inteligensi. Perkembangan Anak Usia Dini.

Anak usia dini memiliki karakter yang khas dan variatif. Kekhasan tersebut akan tampak pada usia 0 sampai 6 tahun. Pada masa ini sangat menentukan pembentukan kepribadian anak dan perkembangan inteligensi. Adapun beberapa masa yang dilalui anak usia dini sebagai berikut:

1) Masa Peka

Masa peka merupakan periode sensitif karena anak mudah menerima stimulus dan menyerap informasi dari lingkungan.

2) Masa Egosentris

Masa egosentris merupakan masa dimana anak memiliki sikap mau menang sendiri, selalu ingin dituruti sehingga perlu perhatian dan kesabaran dari orang dewasa/ pendidik.

3) Masa Berkelompok

Masa berkelompok yaitu masa anakanak senang bermain dengan teman sebayanya, mencari teman yang dapat menerima satu sama lain sehingga anak perlu diberi kesempatan bermain bersama-sama.

4) Masa Meniru

Anak merupakan peniru ulung yang dilakukan terhadap lingkungan sekitarnya.

5) Masa Eksplorasi

Masa menjelajahi pada anak dengan memanfaatkan benda-benda disekitarnya, selalu ingin mencoba, penuh keingintahuan dan melakukan trial and error terhadap benda-benda yang ditemukannya.

\section{Kognitif Anak Usia Dini}

Dunia kognitif anak bersifat kreatif, penuh fantasi, dan sepanjang waktu pemahaman tentang dunia terus meningkat. Teori Piaget (dalam Santrock, 2012, hlm. 27) menyatakan bahwa "anak-anak secara aktif membangun pemahaman mereka mengenal dunia dan melalui empat tahap perkembangan kognitif". Empat tahapan perkembangan kognitif menurut Piaget yaitu:

1) Tahap sensorimotor, berlangsung sejak kelahiran sampai usia 2 tahun. Pada tahap ini anak membangun pengetahuan melalui pengalaman sensoris.

2) Tahap praoperasional, berlangsung sekitar usia 2 tahun sampai 7 tahun. Pada tahap ini anak mulai memahami dunia secara simbolis.

3) Tahap operasional konkrit, berlangsung sekitar usia 7 tahun sampai 11 tahun. Pada tahap ini anak mulai berfikir secara logis mengenai peristiwa-peristiwa seperkonkrit.

4) Tahap operasi formal, berlangsung sekitar usia 11 tahun sampai 15 tahun dan terus berlangsung hingga masa dewasa. Pada tahap ini anak mulai mampu berfikir abstrak, idealis, dan lebih logis.

Berdasarkan tahapan perkembangan kognitif Piaget, anak usia dini berada pada tahap praoperasional. Tahap praoperasional dibagi menjadi dua tahapan yaitu tahap fungsi simbolik dan tahap berfikir intuitif. Pada tahap fungsi simbolik anak mulai mempresentasikan dunia menggunakan simbol seperti mempresentasikan mobil, tanaman, hewan melalui coretan-coretan. Pada tahap pemikiran intuitif anak mulai bernalar dan mengajukan banyak pertanyaan kepada orang dewasa. 


\section{Lambang Bilangan}

Lambang merupakan visualisasi dari berbagai konsep (Depdiknas, 2007, hlm. 10). Misalnya lambang 1 untuk menggambarkan konsep bilangan satu, lambang 2 untuk menggambarkan konsep bilangan dua, dan seterusnya. Bilangan adalah suatu konsep matematika yang digunakan untuk pencacahan dan pengukuran. Simbol ataupun lambang yang digunakan untuk mewakili suatu bilangan disebut lambang bilangan. Menurut Soedjatmoko (dalam Haryanai, 2014, hlm. 45) bahwa nama bilangan adalah nama yang dipergunakan untuk menyebut ataupun menyatakan suatu bilangan. Lambang bilangan atau sering disebut simbol yang dapat dipergunakan untuk menuliskan nama suatu bilangan yang telah disebut. Bilangan merupakan konsep yang abstrak, bukan simbol, bukan pula angka. Lambang bilangan itu biasa kita sebut angka (adjie nahrowi \& R. Deti Rostika, 2009, hlm. 96).

Berdasarkan beberapa pengertian diatas dpat disimpulkan bahwa lambang bilangan merupakan simbol untuk menyatakan bilangan sesui dengan konsep bilangan. Menurut Wahyudi dan Dwi (dalam Haryani, 2014, hlm. 45) menyebutkan beberapa keahlian mengenali lambang bilangan yang harus ditanamkan pada anak yaitu:

1) Pengenalan bilangan

2) Pengenalan lambang bilangan

3) Penggabungan nama dari setiap bilangan dengan bentuk lamang tersebut

4) Aturan urutan nomor bilangan dari 1 sampai 10

5) Kemampuan untuk menggabungkan nomor dengan kumpulan

Pada awalnya anak hanya mampu menyebutkan nama bilangan tanpa mengetahui mkana dari bilangan yang disebutkan. In the beginning, children can say the names of numbers in order. They remember the words, but they do not understand the meaning of what they are saying (Jackman, 2001, 252). Anak mengingat nama bilangan tetapi belum mengerti makna bilangan yang mereka sebutkan, dan seiring dengan perkembangannya lama-kelamaan anak akan mengerti makna dari bilangan

a. Pentingnya Mengenal Lambang Bilangan bagi Anak Usia Dini

Lambang bilangan merupakan bagian dari aspek mendasar matematika. Bagi anak usia dini matematika hanya sebuah pengalaman bukan penugasan. Hasanah (2014, hlm. 2) menyebutkan bahwa kemampuan mengenal lambang bilangan bagi individu merupakan suatu hal yang penting bagi proses bertahan hidup, karena sejak dini anak sudah mulai mengenal dan menggali berbagai dimensi matematis dari dunia mereka.

Asmawati (2014, hlm.64) mengatakan bahwa untuk anak usia 4-5 tahun dalam kemampuan mengenal lambang bilangan mencakup indikator menunjuk lambang bilangan 1-10, meniru lambang bilangan 110, dan menghubungkan/memasangkan lambang bilangan dengan benda-benda sampai 10 (anak tidak disuruh menulis).

b. Perkembangan Mengenal Lambang Bilangan

Perkembangan mengenal lambang bilangan penting untuk diketahui dalam proses pembelajaran mengenal lambang bilangan. Sebelum mengenal lambang bilangan perlu mengetahui perkembnagan mengenal konsep bilangan. Menurut Sujiono (dalam Bahtera, 2016, hlm.22) perkembangan mengenal konsep bilangan mencakup beberapa hal sebagai berikut:

1) Pengenalan kuantitas. Anak-anak menghitung sejumlah benda yang ditentukan, dilakukan secara bertahap 1-10 kemudian 11-20. 
2) Menghafal urutan nama bilangan yaitu menyebutkan nama bilangan dalam urutan yang benar.

3) Menghitung secara rasional. Anak dikatakan memahami bilangan bila mampu menghitung benda sambil menyebutkan nama bilangan, membuat korespondensi satu-satu, menyadari bilangan terakhir yang disebut mewakili jumlah benda dalam 1 kelompok.

4) Menghitung maju. Menghitung 2 kelompok benda yang digabungkan dengan cara menghitung semua dimulai dari benda pertama sampai benda terakhir, menghitung melanjutkan, menghitung benda dengan cara melanjutkan dari jumlah salah satu kelmpok.

5) Menghitung mundur. Menghitung mundur dilakukan dalam operasi pengurangan bilangan, menggunakan bilangan kecil saja.

6) Menghitung melompat yaitu menyebutkan bilangan dengan cara melompat dengan bilangan tertentu.

\section{Playdough}

Playdough berasal dari kata play yang berarti bermain dan dough yang berarti adonan atau plastisin yang dapat dibentuk sesuai dengan keinginan dan kreativitas. Haryani (2014, hlm. 59) mengatakan bahwa playdough adalah salahsatu alat permainan edukatif dalam pembelajaran yang termasuk kriteria alat permainan murah dan memiliki nilai fleksibilitas dalam merancang pola-pola yang hendak dibentuk sesuai dengan rencana dan daya imajinasi. Dewi (2005, hlm. 25) bahwa playdough adalah salah satu bahan permainan edukatif karena dapat mendorong imajinasi anak. Anggraini (dalam Haryani, 2014, hlm. 59) bahwa playdough adalah salah satu aktivitas yang bermanfaat untuk perkembangan otak anak. Dengan bermain playdough anak tak hanya memperoleh kesenangan tapi juga bermanfaaat untuk meningkatkan perkembangan otaknya. Dengan playdough, anak-anak bisa membuat bentuk apapun dengan cetakan atau dengan kreativitasnya masing-masing.

Berdasarkan beberapa pengertian diatas, dapat disimpulkan bahwa playdough merupakan adonan yang mudah dibentuk sesuai dengan imajinasi anak yang mampu memberikan pengalaman menyenangkan bagi anak dan menstimulus berbagai aspek perkembangan.

Playdough sangat cocok untuk anak, karena playdough mudah dibentuk, hal ini sesuai dengan karakteristik anak yang senang memanipulsi benda sebagai bentuk alamiah memahami dunia sekitarnya. Menurut Eliyawati dalam Setianingsih (dalam Dewi, 2005, hlm. 26) bahwa media playdough mempunyai ciri-ciri sebagai berikut:

1) Ditujukan untuk anak usia dini

2) Berfungsi untuk mengembangkan aspek-aspek perkembangan anak usia dini

3) Dapat digunakan dengan berbagai cara, bentuk, dan untuk bermacam tujuan aspek pengembangan atau bermanfaat multiguna

4) Aman atau tidak berbahaya bagi anak

5) Dirancang untuk mendorong aktivitas dan kreativitas

6) Bersifat konstruktif atau ada sesuatu yang dihasilkan

7) Mengandung nilai pendidikan

\section{a. Pentingnya Penggunaan Playdough sebagai Media Pembelajaran}

(NAEYC) menyebutkan bahwa

"Young children love to play playdough.

This simple preschool stape lets children use their imaginations and strengthen the small muscles in their fingers the same muscles they will one day use to hold a pencil and write". Anak-anak sangat suka 
bermain playdough. Tambahkan beberapa alat peraga dari sekitar rumah ataupun sekolah dan playdough merupakan cara yang ampuh untuk mendukung pembelajaran anak. Penggunaan playdough sebagai media pembelajaran memungkinkan anak-anak menggunakan imajinasi mereka, melatih motorik halus sebagai dasar untuk kemampuan menulis, mendukung keterampilan sosial, menstimulus perkembangan bahasa, ilmu pengetahuan, dan keterampilan matematika pada saat yang sama.

Penggunaan playdough menawarkan anak-anak kesempatan belajar yang berharga, mendukung pengembangan dan pembelajaran pada berbagai aspek perkembangan. "Playdough play at home or school supports development and learning in many areas" (NAEYC).Ketika anak-anak menggunakan playdough mereka mengeksplorasi ide-ide dan terus mencoba, membuat bentuk sesuai imajinasi mereka, memuaskan rasa ingin tahu, dan memberikan pengalaman yang membantu anak mengenal dunia sekitarnya. Playdough is a staple play material in the early childhood classroom (Swartz, 2005, hlm. 100). Playdough merupakan bahan bermain pokok di kelas prasekolah. Playdough memberikan pengalaman menyenangkan dan memuaskan untuk anak-anak, mendukung pertumbuhan dan pembelajaran diberbagai aspek.

Cara belajar terbaik bagi anak adalah dengan memanipulasi benda dimana anakanak dapat melihat efek yang mereka temukan dilingkungan sekitar. Young children learn best trough manipulation of materials in which they can see the effects they have on the world around them. (Swartz, 2005, hlm.100). Playdough memberikan pengalaman bagi anak, bereksperimen dengan berbagai cara, sebagai dasar yang kuat untuk pendidikan selanjutnya. b. Cara membuat playdough

Bahan yang dibutuhkan yaitu $1 / 2 \mathrm{~kg}$ tepungterigu, $250 \mathrm{gr}$ garam, $200 \mathrm{ml}$ air matang, pewarnamakanan, 1 sdtminyakgoreng

Cara membuatnya:

- Campur semua bahan (kecuali pewarna) dalam sebuah panci.

- Panaskan panci di atas kompor dengan api kecil sambil diaduk perlahan sampai adonan berubah teksturnya menjadi padat dan lunak serta tidak lengket. (catatan: jika adonan masih lengket, anda hanya perlu memanaskannya lebih lama, panaskan lagi dan aduk sampai adonan padat).

- Angkatpancidanbiarkanadonanmenjadi dinginsebelumdapatdiolahlebihlanjut.

- Pindahkan adonan ke atas nampan yang cukup besar dan remas-remas sampai adonan memiliki tekstur halus secara merata

- Bagi adonan dengan membentuk beberapa bentuk bola untuk diwarnai, sesuai dengan jumlah warna yang diinginkan

- Tahap berikutnya adalah pewarnaan. Ambil sebuah bola adonan, buat lubang di tengah bola lalu teteskan beberapa tetes pewarna makanan. Tutup lubang dengan melipat adonan ke atas. Pipihkan adonan lalu lipat ke samping, dst. Olah adonan sehingga warnanya merata. Lakukan dengan bola-bola adonan lainnya dengan warna yang berbeda-beda. (Catatan: Pada tahap ini pewarna belum tercampur sempurna, sehingga mungkin pewarna yang masih kental mengenai tangan anda. Sebaiknya gunakan sarung tangan plastik atau bungkus tangan anda dengan kantong plastik)

- Setelah bola adonan diwarnai, playdough siap digunakan. 
c. Manfaat penggunaan playdough

Penggunaan playdough memberikan pengalaman menyenangkan bagi anak. Manfaat penggunaan playdough bagi anak yaitu sebagai berikut:

- Mengasah kemampuan berpikir anak. Bagi anak usia dini bermain playdough dapat membantunya membuat karya tiga dimensi melalui imajinasi dan kreativitas serta kemampuannya dalam berpikir

- Mengasah imajinasi. Imajinasi akan memacu kreativitas. Anak dapat membentuk apapun yang diinginkan sesuai dengan kemampuan masingmasing

- Kemampuan berbahasa. Meremas, bergulir, membentuk bola adalah beberapa kata yang sering didengar oleh anak saat menggunkan playdough, ia dapat meningkatka rasa ingin tahunya.

- Kemampuan sosial. Berilah kesempatan kepada anak untuk mengunakan playdough bersama teman-temannya untuk menjalin interaksi yang akrab dengan temantemannya.

- Kemampuan emosional. Anak-anak sering mengungkapkan kebanggan prestasi ketika menggunakan playdough. Melalui playdough anak mengekspresikan perasaan mereka.

\section{METODE}

\section{Desain Penelitian}

Penelitian ini merupakan Penelitian Tindakan Kelas atau PTK (Classroom Action Research). PTK bertujuan untuk meningkatkan kualitas kompetensi guru untuk menyelesaikan masalah pembelajaran dan meningkatkan kualitas pembelajaran melalui tindakan perbaikan. Penelitian ini dilakukan sebagai upaya peningkatan kemampuan anak dalam mengenal lambang bilangan melalui media playdough. Isaac (dalam Muslich, 2009, hlm. 144) menyebutkan bahwa penelitian tindakan kelas didesain untuk memecahkan masalahmasalah yang diaplikasikan secara langsung di dalam kelas. Dalam penelitian ini masalah yang dimaksud adalah belum optimalnya kemampuan anak pada kelompok A TK Wijaya Kusumah / Kartika XIX-26 dalam mengenal lambang bilangan. Alternatif pemecahannya dengan menggunakan playdough sebagai media pembelajaran. Penelitian tindakan kelas ini dilakukan secara kolaboratif oleh peneliti dan guru sebagai mitra dengan mengambil setting alamiah di kelas.

\section{Setting Penelitian}

Penelitian ini dilaksanakan di TK Wijaya Kusumah / Kartika XIX-26 Kecamatan Tawang Kota Tasikmalaya. TK ini telah berdiri sejak tahun 1954 dan terus berkembang baik sampai sekarang. Lokasi sekolah ini berada di Jl. Taman Pahlawan No. 16 Kelurahan Cikalang Kecamatan Tawang.

Penelitian tindakan kelas ini dilaksanakan pada akhir semester dua tahun pelajaran 2016/2017.

\section{Subjek Penelitian}

Subjek dalam penelitian ini adalah siswa TK Wijaya Kusumah / Kartika XIX26 Kecamatan Tawang Kota Tasikmalaya pada kelompok A yang berjumlah 12 anak yang terdiri dari 8 anak laki-laki dan 4 anak perempuan.

\section{Variabel dan Definisi Operasional Variabel Penelitian}

Variabel proses dalam penelitian ini adalah kemampuan guru dalam mengelola pembelajaran menggunakan media playdough. Variabel hasil dalam penelitian ini adalah kemampuan anak mengenal lambang bilangan. 
Kemampuan guru dalam mengelola pembelajaran menggunakan playdough meliputi tahap persiapan, pelaksanaan, dan penilaian pembelajaran menggunakan playdough. Playdough yang dimaksud dalam penelitian ini adalah media dari bahan alam yaitu terigu yang dicampur dengan air, garam, pewarna makanan, dan minyak goreng.

Kemampuan mengenal lambang bilangan yang dimaksud dalam penelitian ini adalah menunjuk lambang bilangan 110, meniru lambang bilangan 1-10, menghubungkan lambang bilangan dengan jumlah benda sampai 10 .

\section{Prosedur Penelitian}

1) Perencanaan

Pada tahap ini peneliti menentukan langkah-langkah pengembangan sebagai upaya perbaikan terhadap masalah utama yang teridentifikasi, yakni: (1) Bekerjasama bersama observer menetapkan urutan materi pembelajaran dan cakupannya, (2) Membuat RPPH, (3) Membuat media playdough, (4) Membuat lembar kerja anak mengenai lambang bilangan kemudian dilapisi plastik mika agar playdough tidak menempel pada kertas LKA. Tiap lembar kerja anak mengenalkan satu lambang bilangan, (5) Menyiapkan instrumen penelitian, (6) Memvalidasi instrumen penelitian.

\section{2) Pelaksanaan tindakan kelas}

Pada tahap ini peneliti melaksanakan pembelajaran sesuai dengan yang telah direncanakan. Peneliti melaksanakan kegiatan pembelajaran dengan menggunakan media playdough untuk mengenal lambang bilangan.

Pada pelaksanaan pembelajaran langkah-langkah yang dilakukan adalah; (1) peneliti membuka pembelajaran dengan salam, doa, dan nyanyian. Kemudian peneliti menjelaskan terlebih dahulu tentang kegiatan yang akan dilakukan yaitu mengenal lambang bilangan dengan menggunakan media playdough. Anak-anak diinstruksikan mengisi lembar kerja yang disediakan mengenai lambang bilangan dengan media playdough, (2) mengadakan interaksi pembelajaran yang terdiri atas memberikan kesempatan kepada peserta didik untuk bertanya, membahas materi, melibatkan peserta didik untuk lebih aktif, menggunakan media pembelajaran dengan penjelasan dan sumber pembelajaran dalam rangka mencapai tujuan, (3) peserta didik diberikan kesempatan untuk istirahat bermain dan makan, (4) menutup pembelajaran dengan kegiatan evaluasi akhir, pembahasan singkat, menarik kesimpulan refleksi dan tindak lanjut. Pelaksanaan tindakan dilakukan selama beberapa pertemuan sesuai dengan skenario.

3) Observasi dan evaluasi

Sementara kegiatan pembelajaran berlangsung peneliti mengamati pelaksanaan pembelajaran dengan menggunakan media playdough. Hal yang diamati yaitu semua perilaku (kemampuan) anak dalam mengikuti kegiatan. Setelah mengamati pada kegiatan akhir/penutup dilakukan evaluasi/penilaian. Aspek-aspek yang dinilai yaitu kemampuan anak dalam menunjuk lambang bilangan 1-10, meniru lambang bilangan 1-10, menghubungkan lambang bilangan dengan benda-benda sampai 10. Data yang diperoleh dipresentasekan untuk melihat peningkatan anak dalam kemampuan mengenal lambang bilangan.

\section{4) Refleksi}

Setelah data observasi dianalisis, peneliti melakukan refleksi terhadap kegiatan pembelajaran yang telah dilakasanakan. Pada tahap ini peneliti berusaha untuk mengetahui kemampuan 
anak didik dalam pembelajaran yang telah dilakukan. Hasil tersebut digunakan untuk menentukan tindakan pada siklus berikutnya.

Adapun langkah-langkah dalam refleksi tindakan yaitu merinci dan menganalisis efektifitas pembelajaran yang didasarkan pada hasil observasi aktivitas anak didik, data hasil observasi guru, serta hambatan yang dihadapi guru, minat / ketertarikan belajar anak terhadap media playdough untuk mengisi lembar kerja yang disediakan. Langkah kedua mengidentifikasi permasalahan yang sudah dan belum terpecahkan atau yang muncul selama pembelajaran berlangsung dengan mengisi skor penilaian belum berkembang, mulai berkembang, berkembang sesuai harapan, dan berkembang sangat baik pada lembar observasi yang disediakan.

\section{Teknik Pengumpulan Data}

Terdapat dua macam teknik pengumpulan data dalam penelitian ini yaitu observasi dan dokumentasi.

\section{Instrumen Pengumpulan Data}

Instrumen penelitian yang digunakan dalam penelitian ini adalah sebagai berikut

a. Lembar observasi kemampuan guru dalam merencanakan pembelajaran

b. Lembar observasi kemampuan guru dalam perencanaan, produk, dan penggunaan media playdough

c. Lembar observasi kemampuan guru dalam proses pembelajaran

d. Lembar observasi kemampuan anak mengenal lambang bilangan

\section{Teknik Analisis Data}

Dalam penelitian ini data dianalisis dengan cara deskriptif kualitatif. Teknik statistik yang digunakan untuk mendeskripsikan hasil penelitian dari data kualitatif antara lain: persen, kuartil, ranking, mean, mode median, bagan, grafik, dan tabel (Dimyati, 2013, hlm. 105). Penelitian ini menggunakan teknik presentase dalam mendeskripsikan data kualitatif hasil penelitian. Dari hasil penelitian yang telah dilakukan selanjutnya dipresentasekan dengan rumus presentase sebagai berikut:

$$
\mathrm{NP}=\frac{\mathrm{R}}{\mathrm{SM}} \times 100 \%
$$

Keterangan:

$\begin{array}{lll}\mathrm{NP} & = & \text { nilai persen yang dicari } \\ \mathrm{R} & = & \text { skor mentah yng } \\ \text { diperoleh } & & \text { skor maksimum ideal } \\ \mathrm{SM} & \text { dari nilai yang ada }\end{array}$

(Purwanto dalam Ulum, 2014, hlm. 50)

\section{HASIL DAN PEMBAHASAN}

Penelitian mengenai peningkatan kemampuan anak mengenal lambang bilangan telah dilakukan melalui tiga siklus yaitu siklus I, siklus II, dan siklus III. Hasil yang diperoleh dari penelitian ini berupa lembar observasi yang kemudian digunakan oleh peneliti untuk mengetahui peningkatan kemampuan anak dalam mengenal lambang bilangan. Siklus I dilaksanakan pada tanggal 26 April 2017 dengan tema alam semesta subtema benda langit sub-sub tema matahari. Siklus II dilaksanakan pada tanggal 4 Mei 2017 dengan tema alam semesta sub tema gejala alam sub-sub tema pelangi. Siklus III dilaksanakan pada tanggal 9 Mei 2017 dengan tema tanaman sub tema buahbuahan sub-sub tema apel. Setiap siklus menggunakan langkah yang sama yaitu perencanaan, pelaksanaan, observasi, dan refleksi. Adapun pembahasan hasil dari penelitian yang telah dilaksanakan baik siklus I, siklus II, siklus III adalah sebagai berikut:

Berikut ini adalah hasil perbandingan peningkatan kemampuan anak mengenal 
lambang bilangan melalui penggunaan play dough dari mulai siklus I hingga siklus III:

Tabel 1

Hasil Penigkatan Kemampuan Anak Mengenal Lambang Bilangan

Pada Siklus I, Siklus II, Siklus III

\begin{tabular}{lllllllll}
\hline \multirow{2}{*}{ Indikator } & \multicolumn{1}{l}{ BB } & \multicolumn{1}{l}{ MB } & \multicolumn{3}{l}{ BSH } & BSB \\
\cline { 2 - 9 } & $\mathrm{f}$ & $\%$ & $\mathrm{f}$ & $\%$ & $\mathrm{f}$ & $\%$ & $\mathrm{f}$ & $\%$ \\
\hline Menunjuk & 1 & 8,3 & 4 & 33,3 & 4 & 33,3 & 3 & 25,0 \\
\hline Meniru & 0 & 0,0 & 4 & 33,3 & 4 & 33,3 & 4 & 33,3 \\
\hline Menghubungkan & 1 & 8,3 & 4 & 33,3 & 3 & 25,0 & 4 & 33,3 \\
\hline Rata-Rata & $\mathbf{1}$ & $\mathbf{5 , 6}$ & $\mathbf{4}$ & $\mathbf{3 3 , 3}$ & $\mathbf{4}$ & $\mathbf{3 0 , 6}$ & $\mathbf{4}$ & $\mathbf{3 0 , 6}$ \\
\hline Siklus 2 & & & & & & & & \\
\hline Menunjuk & 0 & 0,0 & 2 & 16,7 & 3 & 25,0 & 7 & 58,3 \\
\hline Meniru & 0 & 0,0 & 1 & 8,3 & 2 & 16,7 & 9 & 75,0 \\
\hline Menghubungkan & 0 & 0,0 & 1 & 8,3 & 4 & 33,3 & 7 & 58,3 \\
\hline Rata-Rata & $\mathbf{0}$ & $\mathbf{0 , 0}$ & $\mathbf{1}$ & $\mathbf{1 1 , 1}$ & $\mathbf{3}$ & $\mathbf{2 5 , 0}$ & $\mathbf{8}$ & $\mathbf{6 3 , 9}$ \\
\hline Siklus 3 & & & & & & & & \\
\hline Menunjuk & 0 & 0,0 & 0 & 0,0 & 2 & 16,7 & 10 & 83,3 \\
\hline Meniru & 0 & 0,0 & 0 & 0,0 & 1 & 8,3 & 11 & 91,7 \\
\hline Menghubungkan & 0 & 0,0 & 0 & 0,0 & 2 & 16,7 & 10 & 83,3 \\
\hline Rata-Rata & $\mathbf{0}$ & $\mathbf{0 , 0}$ & $\mathbf{0}$ & $\mathbf{0 , 0}$ & $\mathbf{2}$ & $\mathbf{1 3 , 9}$ & $\mathbf{1 0}$ & $\mathbf{8 6 , 1}$
\end{tabular}

Berdasarkan tabel 4.18 tersebut dapat dilihat peningkatan yang cukup signifikan. Hal ini dibuktikan dengan kemampuan anak mengenal lambang bilangan terus meningkat dari mulai siklus I hingga siklus III. Pada siklus I kemampuan anak mengenal lambang bilangan pada kriteria berkembang sangat baik (BSB) diperoleh rata-rata sebanyak 4 anak atau dengan ratarata persentase $30,6 \%$, selanjutnya pada siklus II meningkat menjadi 8 anak atau dengan rata-rata persentase $63,9 \%$ anak berkembang sangat baik, dan kemampuan anak mengenal lambang bilangan pada siklus III meningkat signifikan menjadi 10 anak atau dengan rata-rata persentase $86,1 \%$ pada kriteria berkembang sangat baik.
Lebih jelas hasil perbandingan peningkatan kemampuan anak mengenal lambang bilangan melalui penggunaan media play dough dari mulai siklus I hingga siklus III dapat dilihat pada grafik sebagai berikut:



\section{KESIMPULAN}

Berdasarkan hasil penelitian yang telah dilakukan dapat disimpulkan bahwa peningkatan kemampuan anak mengenal lambang bilangan melalui media play dough dapat ditunjukkan dengan adanya peningkatan hasil observasi siklus I, siklus II, dan siklus III. Sebelum dilaksanakan tindakan dapat diketahui bahwa kemampuan anak mengenal lambang bilangan pada kriteria berkembang sangat baik rata-rata sebanyak 3 anak atau dengan rata-rata persentase $27,8 \%$ Pada pelaksanaan siklus I, kemampuan anak mengenal lambang bilangan pada kriteria berkembang sangat baik meningkat menjadi 4 anak atau dengan rata-rata persentase $30,6 \%$. Setelah pelaksanaan siklus II, kemampuan anak mengenal lambang bilangan pada kriteria berkembang sangat baik meningkat menjadi 8 anak atau dengan rata-rata persentase $63,9 \%$. Setelah pelaksanaan siklus III kemampuan anak mengenal lambang bilangan pada kriteria 
berkembang sangat baik meningkat signifikan menjadi 10 anak atau dengan rata-rata persentase $86,1 \%$. Dari hasil tersebut dapat dketahui bahwa kemampuan anak mengenal lambang bilangan telah mencapai kriteria keberhasilan yang diharapkan peneliti.

Untuk mencapai keberhasilan pembelajaran dalam meningkatkan kemampuan anak mengenal lambang bilangan maka peneliti dapat memberikan saran sebagai berikut:

1. Bagi guru

Sebaiknya guru memilih berbagai media pembelajaan yang menarik dalam setiap kegiatan pembelajaran, salahsatunya dengan menggunkan media play dough untuk mengembangkan kemampuan anak mengenal lambang bilangan.

2. Bagi sekolah

Sebaiknya pihak sekolah menyesuaikan sarana dan prasarana untuk memfasilitasi guru dalam mengembangkan berbagai potensi anak. Pihak sekolah hendaknya memberikan latihan/mengikuti seminar agar terciptanya guru yang kreatif dan inovatif untuk mengembangkan kemampuan mengajarnya.

3. Bagi peneliti

Peneliti selanjutnya disarankan untuk mengembangkan media play dough sebagai kegiatan untuk meningkatkan kemampuan anak mengenal lambang bilangan maupun kemampuan anak lainnya.

\section{DAFTAR PUSTAKA}

Adjie, $\quad \mathrm{N} \quad$ \&Rostika, R.D. (2009).Konsepdasarmatematika. Bandung: UPI PRESS.

Ardyatmika, A., Parmiti, D.\& Ujianti, P. (2016). Penerapan metode bermain melalui media playdough untuk meningkatkan kemampuan motorik halus anak kelompok A, 4(2), hlm.110.

Asmawati, L. (2014). Perencanaan pembelajaran PAUD. Bandung: PT. Remaja Rosdakarya.

Bahtera, F.S. (2016). Peningkatan Kemampuan Mengenal Lambang Bilangan Melalui Bermain Kereta Gantung Bernomor di Kelompok A TK Anggrek Kota Banjar. (Skripsi). FIP Universitas Pendidikan Indonesia Kampus Tasikmalaya, Tasikmalaya.

Cross, C.T. (t.t). Mathematics learning in earlychildhood. Washington, DC: The National Academies Press.

Davies, D. (2011). Child development a practitioner's guide. Newyork: The guilford press.

Departemen Pendidikan Nasional. (2007). Pedoman pembelajaran permainan berhitung permulaan di taman kanak-kanak. Jakarta: Depdiknas.

Dewi, S.S. (2016). Peningkatan kemampuan mengenal angka 1-10 melalui permainan menjepit kartu angka di kelompokA TK Kartika IX10 / Cangkurileung Kecamatan Tawang Kota Tasikmalaya. (Skripsi). FIP Universitas Pendidikan Indonesia Kampus Tasikmalaya, Tasikmalaya.

Dimyati, J. (2013). Metodologi penelitian pendidikan dan aplikasinya pada pendidikan anak usia dini (PAUD). Jakarta: Kencana Prenadamedia Group.

Hasanah, S. (2014). Upaya peningkatan kemampuan mengenal lambang bilangan melalui media permainan memancing ikan pada anak, 2(2), hlm. 1-8.

Jackman, H.L. (2001). Early education curriculum: a child's connection to the world. Coumbia: Delmar.

Latif, M. dkk. 2013. Orientasi baru pendidkan anak usia dini:teori dan aplikasi. Jakarta: Prenada Media group.

Muslich, M. (2009). Melaksanakan PTK itu mudah. Jakarta: Bumi Aksara. 
Mutiah, D. (2012). Psikologi bermain anak usia dini. Jakarta: Prenada Media group.

Peraturan Menteri Pendidikan dan Kebudayaan Republik Indonesia. (2014). Kurikulum 2013 pendidikan anak usia dini. Jakarta: Permendikbud.

Peraturan Menteri Pendidikan dan Kebudayaan Republik Indonesia. (2014). Standar isi tentang tingkat pencapaian perkembangan anak. Jakarta: Permendikbud.

Ramaini. (t.t). Peningkatan kemampuan mengenal konsep bilangan melalui permainan tabung pintar di TK negeri pembina lubuk basung, 1(1), hlm. 1-13.Santrock, J.W. (2012). Life span development (perkembangan masa hidup).

Sriningsing, N. (2009). Pembelajaran mtk terpadu untuk AUD . Bandung: Pustaka II.

Sugiyono. (2010). Metode penelitian kuantitatif dan kualitatif dan $R \& D$. Bandung: Alfabeta.

Sujiono, Y.N. (2012). Konsep dasar pendidikan anak usia dini. Jakarta: PT Indeks.

Sukardi, H.M. (2012). Metode penelitian pendidikan tindakan kelas: implementasi dan pengembangannya. Jakarta: Bumi Aksara.

Trisniwati. (2014). Peningkatan kemampuan mengenal huruf melalui metodepermainan kartu huruf pada kelompok B1 TK ABA Ketanggungan Wirobrajan. (Skripsi). FIP Universitas Negeri Yogyakarta, Yogyakarta.

Ulum ,Irfatul. (2014). Peningkatan pemahaman konsep bilangan melalui permainan memancing angka pada anak kelompok a di RA masyithoh kalisoka triwidadi Pajangan Bantul. (Skripsi). FIP Universitas Negeri Yogyakarta, Yogyakarta.

Wortham, S.C. (2006). Early childhood curriculum: developmental bases for learning and teaching. Ohio: Pearson Merrill Prentice Hall.
Wulandari, P., I Nyoman W. \& Luh A. T. (2014). Penerapan numbered head together berbantuan media kartu angka untuk meningkatkan kemampuan mengenal lambang bilangan anak, 2(1), hlm. 1-10.

Yunikowati, D. (2014). Peningkatan kemampuan kognitif dalam mengenal konsep bilangan dengan permainan cetak angka playdough pada anak, 2(2), hlm. 56-67.

Sumber online:

Haryani, C. (2014). Penerapan metode bermain dengan media playdough dalam meningkatkan kemampuan mengenal konsep bilangan dan lambang bilangan pada anak usia dini. (Skripsi). FKIP Universitas Bengkulu. [online]. Diakses dari http:http://repository.unib.ac.id/8756/ 1/I,II,III,II-14-chi.FK.pdf.

Swart, Mallary I. 2005. Playdough: what's standar. national association for the education of young children (NAEYC). [online]. Diakses dari http://www.naeyc.org/files/tyc/file/T YC V3N3 Swartz.pdf.

Tim Olvista. (2011). Membuat sendiri playdough. [online]. Diakses darihttp://olvista.com/membuatsendiri-playdough-plastisin-mainan/. 